\title{
Working Woman Sexual Harassment Phenomenon in Makassar
}

\author{
Dyan Fauziah Suryadi ${ }^{1}$, Rohani $^{2}$ \\ \{dyanfausiah@gmail.com ${ }^{1}$, rohanirohani.stieypup@gmail.com ${ }^{2}$ \}
}

STIE Yayasan Pendidikan Ujung Pandang, Makassar, Indonesia ${ }^{1,2}$

\begin{abstract}
Women experience various forms of sexual harassment that potentially occur at home, office, and public spaces. This study aims to describe sexual harassment for working women in Makassar. This study involved ten adult women who had ben sexually harassed verbally and physically by their superiors and coworkers. The design of this research is phonology that aims to understand one's life experiences, how an event has an impact on his daily life. Data is collected by conducting depth interviews with the subject and several significant people to fulfill the required information. This study finds that after experiencing sexual harassment, the subjects are afflicted to stress that caused by the position of the perpetrator in the workplace, the frequency of sexual harassment, the intensity of the subject meeting with the perpetrator, the number of perpetrators, the behavior that appears after the incident, and the negative feelings that arise due to sexual harassment.
\end{abstract}

Keywords: Sexual Harassment, Work Stress and Employee Performance.

\section{Introduction}

2018 Annual Report Komnas Perempuan shows something new, based on reports of violence in the private/personal sphere that are received by service providers, there is an increase in the number of violence against girls and is quite large, as many as 2,227 cases. While the number of violence against wives still ranks first at 5,167 cases, and then violence in courtship is the third-highest number after violence against children at 1,873 cases. Violence in the public sphere reached 3,528 cases (26\%), where sexual violence ranked first in 2,670 cases (76\%), followed by physical violence: 466 cases (13\%), psychological violence 198 cases $(6 \%)$, and the special category is trafficking 191 cases (5\%), and migrant worker cases 3 cases. The three most common types of sexual violence in the community domain are sexual abuse (911 cases), sexual harassment (708 cases), and rape (669 cases). [1] These data indicate that women experience various forms of sexual harassment by anyone who does not only occur at home, in the office, even in the public room, even women have the potential to experience sexual harassment.

One form of sexual harassment is sexual harassment that occurs at work, including unwanted sexual acts, requests for sexual pleasure, and sexual treatment because of sex [2]. Self harrasement affects not only the world of work of victims, but victims also experience physical suffering, mentally, emotionally, and financially that can destroy victims.

The National Institute for Occupational Safety and Health (NIOSH) reports that women workers have a higher risk of experiencing work stress than men, and one of the biggest sources of stress is sexual harassment. An employee is, of course, faced with a difficult position when they accept sexual harassment behavior from their superiors. On the one hand, they become 
victims and want to demand justice from the sexual harassment they received, but on the other hand they cannot do anything when considering that the sexual harasser is their own boss. There was fear that if they reported this incident they would be fired or transferred because they were considered to be lying about their report. This triggers inner turmoil in employees who are victims of sexual harassment and become depressed at work [3].

\section{Literature Review}

\subsection{Sexual Harassment}

Sexual harassment refers to acts of sexual nuance that are conveyed through physical or nonphysical contact that target a person's sexual or sexual parts of the body resulting in discomfort, demeaning someone's dignity, and possibly to cause health problems and threaten safety. Shame, anger, hate, offense and so on are negative reactions that arise as a result of all kinds of behaviors that lead to sexual things that are not expected and carried out unilaterally by the offender to the target victim. The range of sexual harassment is very broad, which includes: flirting, cheeky whistling, sex or gender connotation comments, porn humor, pinching, poking, patting or touching on certain body parts, certain movements or cues that are sexual in nature, solicitation for dating with a lure- lure or threat, an invitation to have sexual relations to rape. Sexual harassment can occur anywhere and at any time [4]

There are two types of sexual harassment, quid pro quo harrasement, and hostile environment harassment. In the quid pro quo harrasement, actions are implied by touch or suggestive comments. Self harassment is said, if the victim loses economic benefits and as a result of the rejection of the request and sexual treatment of the offender. In the quid pro quo harrasement, the perpetrators are in control of the target and the involvement of victims in work. The second type is the hostile environment harassment, raising more questions. Hostile environment harassment when sexual behavior is undesirable actors has one of two types of impact. This interferes with performance or creates a hostile, offensive, or threatening work environment. This behavior changes the experience of workers in the workplace, which causes the work environment to be a place that is sexually required, intimidating, or offensive. Perpetrators can be supervisors or co-workers who make repeated offensive comments or unnecessary physical contact to the victim [5]

Sexual harassment can cause serious harm to victims, their families, and other coworkers. Sexual harassment also has a damaging effect on the entire workplace. The victim's work performance declines because the pressure of sexual harassment diverts her from work. Harassment can limit women's access to learning opportunities [6].

The incidence of sexual harassment led to negative feelings, such as anger, sadness, fear, resentment, worry, and shame. These negative feelings explained by Boland as a result of sexual harassment also make the victim experience emotional problems. Furthermore, Boland put forward the effects of sexual harassment incidents : emotional impacts, physical impacts, and economic effects [2]

Some of the effects that may result from sexual harassment incidents are as follows:

1. Emotional impact

Emotional trauma can paralyze someone like a visible physical injury. Sexy harassment is shameful and degrading, and can cause victims who reduce self-confidence and self- 
esteem. If something is not too severe, if repeated, it can have a serious and stressful effect on workers. Many cases of sexy harassment are repeated and can last from one to six months or more. Workplace. The emotional effects of sexual abuse also affect the desire to work at all. Confidence. He may be incompetent and question his desire to work in an area that cannot. Emotionally, victims often feel ashamed and ashamed to be targets of abuse.

2. Impact on physical

The victim may not realize it, but has emotional stress that can - and does indeed have a direct effect on other bodily functions. Lack of sleep can cause changes, which can cause pain, pain, or be overcome by disease.

3. Economic impact

Sexy harassment may have a severe economic toll on the victim: training, promotion, or salary increase. In retaliation for approval, he may be transferred to a difficult position or removed from his family and support. When applying is made, it can cause division at work. Certain employees can side with one party or another party. Rumors factories can improve the situation. Many women leave their jobs every year and leave. The effect of the harassment section can follow from the workplace because it might have an impact on the record and reference output.

\subsection{Job Stress}

Stress is an unexpected reaction that arises as a result of the high environmental demands of a person [7]. Stress is a dynamic condition in which an individual is faced with an opportunity, demand, or resource related to what the individual desires and whose outcome is seen as uncertain and important [8]. Claims are responsibilities, pressures, obligations, and even uncertainties faced by individuals in the workplace. Resources are things (or things) that are within the control of an individual that can be used to meet demands.

Beehr and Newman as quoted by Luthans interpret work stress as a condition that occurs as a result of interactions between employees with their work and is characterized or characterized by human changes that force them to deviate from their normal functions [9].

According to Ivancevich and Matteson, "work stress is defined as an adaptive response (response adjustment) mediated by individual differences and / or psychological processes, as a result of environmental actions, situations or events that cause excessive physical and / or psychological demands on a person [10]." A compressor is an external event or situation that has the potential to endanger a person. For an action, situation, or event to produce stress, it must be perceived by the individual as a source of threats, challenges, or dangers. If there are no perceived consequences - good or bad -, there is no potential for stress. Three factors determine whether an experience will produce stress, including interests, uncertainty, and duration.

The effects of stress can be grouped into three general categories: psychological symptoms, psychological symptoms, and behavioral symptoms. Physiological symptoms are the initial influence of stress, usually in the form of physiological symptoms (metabolism, increased heart rate, and breathing, headaches). Psychological symptoms, stress related to job dissatisfaction can lead to work-related. Behavioral symptoms include changes in the level of productivity, absenteeism, and employee turnover, as well as changes in eating habits, smoking patterns, alcohol consumption, stuttering speech, anxiety, and sleep disorder. 


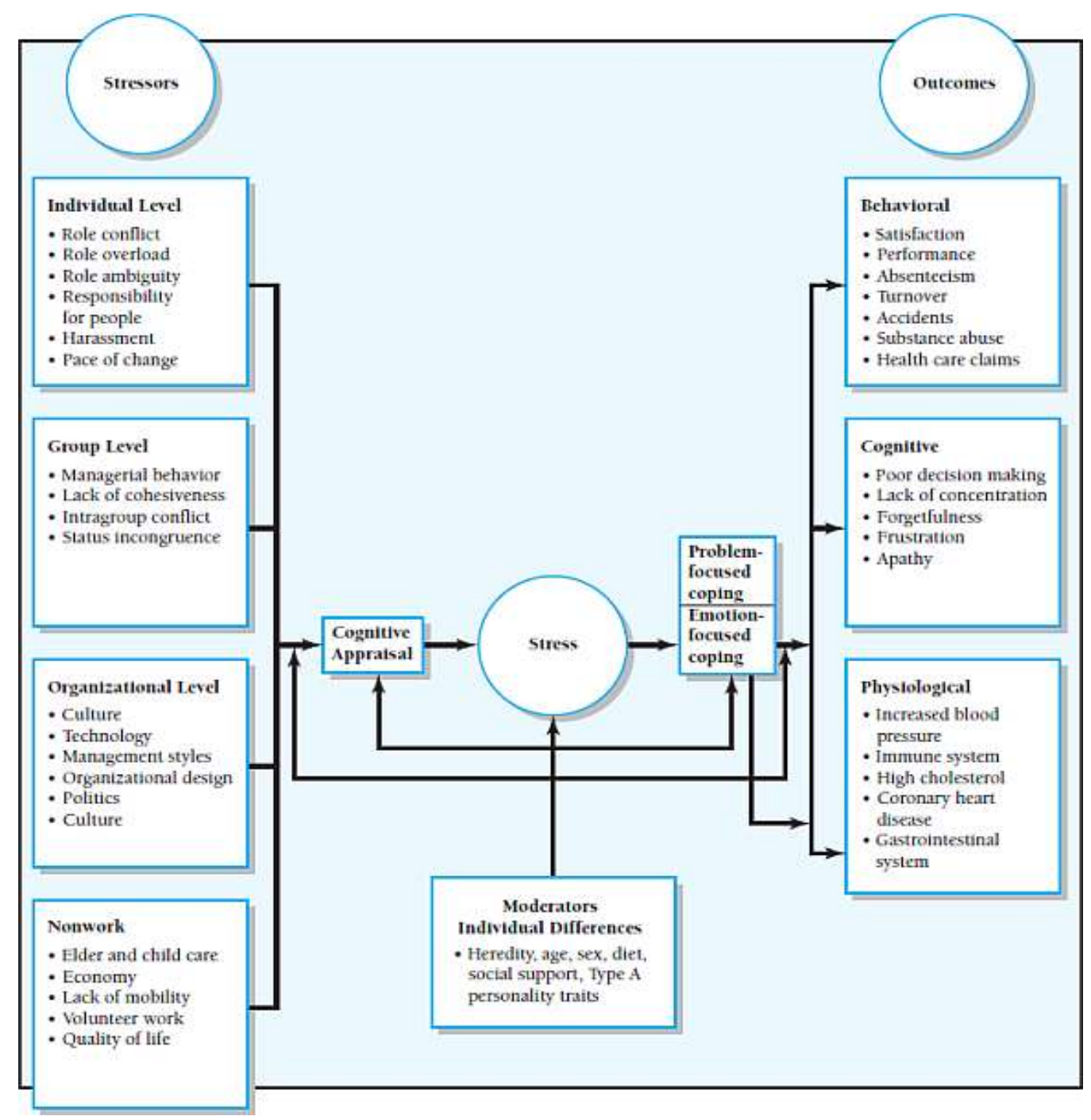

Fig.1. Model of Stressors, Stress, and Outcomes

The model shown in Figure 1 illustrates the relationship between organizational stressors, stress, and outcomes. By definition, stress is a response to an action, situation, or event that places special demands on someone. Stressors are divided into four main categories: individuals, groups, organizations, and other things outside of work. The first three stressor categories relate to work. Work-related and non-work-related stress experiences create behavioral, cognitive, and physiological outcomes. The model states that the relationship between stress and outcomes (individuals and organizations) is not always direct, nor is the relationship between stressors and stressors. This relationship might be influenced by moderator stress. Individual differences such as age, social support mechanisms, and personality are introduced as potential moderators. Moderator is a valuable attribute that influences the nature of a relationship. 


\subsection{Employee Performance}

Performance is a result of work achieved by a person in carrying out the tasks assigned to him based on skill, experience, and sincerity as well as time. The purpose of the job appraisal is basically to measure employee responsibilities and as a basis for employee improvement and development [11].

Byars and Rue in Sutrisno revealed that work performance or achievement is the level of ability and understanding of a person towards a given task (work) that is seen from the results of the work [12].

Ability and skills, background, and demographics are individual factors that influence performance. Perception, attitude, personality, motivation, job satisfaction, and work stress are psychological factors which are the second factors that affect performance. While the third factor that affects performance is the organizational factor which consists of leadership, compensation, conflict, power, organizational structure, job design, organizational design, and career. Ability and skills play an important role in individual behavior and performance. An ability is a trait (innate or learned) that allows someone to do something mental or physical. Skills are competencies related to tasks such as computer operating skills or clear communication skills for group goals and missions [13]. Other opinions expressing factors that affect employee performance are as follows:

1. Ability, namely the ability in a field that is influenced by adequate talent, intelligence (intelligence) and interest.

2. Willingness, i.e., a willingness to provide the best capability for company goals

3. Energy, which is a source of strength from within a person. With energy, a person is able to respond and react to whatever is needed in managing the job for the better.

4. Technology, i.e. the application of existing knowledge to facilitate the work.

5. Compensation, which is something that is received by employees as a reward for performance and benefit him.

6. Clarity of purpose, namely directed work, has a clear focus so as to provide optimal achievement.

7. Security, namely the human need to feel safe in the work environment as an effort to carry out work [14].

\section{Research Methodology}

\subsection{Research design}

This research is qualitative in that it explores and understands the meaning that some individuals or groups of people think is derived from social or humanitarian problems [15]. The design of this study is phenomenology, which aims to understand one's life experiences, how an event impacts his daily life.

\subsection{Research subject}

This research using the phenomenological method of taking a research subject who has experience of the phenomenon [16]. Based on this, the researcher used a purposive technique by establishing criteria in the subject selection, so that the subjects in this study were working 
women and adults who experienced sexual harassment. In addition, researchers also took the subject using snowball sampling techniques, i.e. subjects that met the criteria obtained through the information of the researcher's acquaintances.

\subsection{Data collection technique}

The data collection process used in this study is in-depth interviews with research subjects and several significant people who are deemed necessary in gathering information.

\subsection{Data analysis technique}

Data analysis in this study began by examining all available data from various sources. The procedures for analyzing data in this study refer to the following:

1. Make a list of important questions about how individuals experience the topic (data horizontalisation). Compile a list of non-repetitive and overlapping questions.

2. Taking these important statements, then grouping them into larger units of information (units of meaning).

3. Write a description of the "what" experienced by the participants with the phenomenon (textural description)

4. Write a description of "how" the experience took place (structural description), and the researcher discusses the setting and context in which the phenomenon is experienced.

5. Write a joint description of the phenomenon by entering textural descriptions and structural descriptions [16].

\section{Result and Discussion}

\subsection{Results}

This study involved ten women working in Makassar City, who had experienced sexual harassment at work. Respondents' identities are illustrated through table 1 below:

Tabel 1. Respondents' Identities

\begin{tabular}{ccccc}
\hline No & Subject & Age & Occupation & Marital status \\
\hline 1 & AT & 34 years old & Honorary employee & Single \\
2 & NI & 36 years old & Honorary employee & Married \\
3 & SW & 32 years old & BUMN employee & Single \\
4 & SS & 23 years old & BUMN employee & Single \\
5 & SR & 32 years & Private employees & Widow \\
6 & NN & 44 years old & Salon employee & Widow \\
7 & RD & 27 years old & Restaurant clerk & Widow \\
8 & AW & 51 years old & Government employees & Widow \\
9 & YN & 25 years old & Private employees & Single \\
\hline
\end{tabular}

In general, the subject experienced sexual harassment in the work environment. Two subjects experienced sexual harassment outside the work environment. Overall, the perpetrators of sexual harassment are people who work with the subject. Four subjects experienced sexual 
harassment by their superiors, while six other subjects experienced sexual harassment from coworkers.

The type of sexual harassment experienced by the subject also varies. Nine subjects experienced sexual harassment, in the form of touch in the buttocks, breasts, and genitals. One subject experienced sexual harassment in verbal forms, such as comments about the body shape of the subject and sexual harassment by almost all colleagues. The frequency of sexual harassment experienced by the subjects was six people experienced once, one person experienced it twice, and three people experienced it more than twice.

The occurrence of sexual harassment affects the performance of several subjects. One subject experienced a decrease in performance, such as often making mistakes and starting to make excuses for not coming to work. Three subjects become less able to focus their attention on their work, which then makes work performance less than optimal. One subject person will feel alert when looking at the perpetrator, so the subject becomes less focused.

However, two subjects who let the behavior of the perpetrators, get a raise, even though the work performance is less than the maximum. Different things happen to two subjects. The incident did not affect the performance due to the lack of intensity in meeting with the perpetrators and also caused by the subject's decision to resign. Different things happen to a subject, even though the subject only meets with actors when there is a similar activity, the subject chooses not to participate in the activity.

Based on the results of The Workplace Stress Scale, it was found that subjects who experienced sexual harassment experienced various levels of stress. The causes of stress experienced by the subject after the sexual harassment event vary, such as the position of the perpetrator in the workplace, the frequency of sexual harassment, the intensity of the subject meeting with the perpetrator, the number of perpetrators, the behavior that appears after the incident, and the negative feelings that arise due to sexual harassment .

One subject who does not experience stress because the subject only meets with the perpetrators while participating in the same activity. Subjects who experience mild stress are influenced by the behavior that appears after the incident, in the form of reporting the perpetrator, which then makes the perpetrator expelled, and decides to get out of the office so as not to meet the offender. Causes of the subject experiencing stress are classified as diverse. One subject experienced moderate stress because they were still in the same work environment as the perpetrators, even though they had different branches.

The cause of stress is in one subject is out of the office. But the position of the offender who is a boss, makes the subject finally experience feelings of fear and worry every time the boss in a new workplace calls the subject into the room. Different causes occur in two subjects who are also experiencing moderate stress, in the form of the frequency of sexual harassment that repeatedly occurs and for years.

The causes of severe stress on the subject also vary. One subject experienced severe stress due to the intensity of meeting the actors quite often, resulting in the subject deciding to quit his job. One other subject experienced severe stress due to the position of the principal who was the boss and the subject was still working in the same office as the perpetrator. Another cause of severe stress in one subject is sexual harassment experienced in verbal form and is carried out by almost all co-workers. The subject is also still in the same office as the perpetrators.

Other data found is the influence of sexual harassment events on the subject's performance at work. However, this only happened in eight subjects, while the other two subjects did not experience changes in performance. Things that cause sexual harassment events affect performance are the intensity of the subject meeting with the perpetrators classified as frequent, the position of the perpetrator in the workplace which is the subject's supervisor, repeated sexual 
harassment, and the number of perpetrators where verbal sexual harassment is practiced by almost all co-workers.

Subjects who report perpetrators and then have them removed, do not experience changes in performance. Other subjects who decide to move branches, making the subject rarely meet with others, so that performance does not decrease. Sexual harassment phenomena for working women in Makassar City, illustrated in the chart below: 


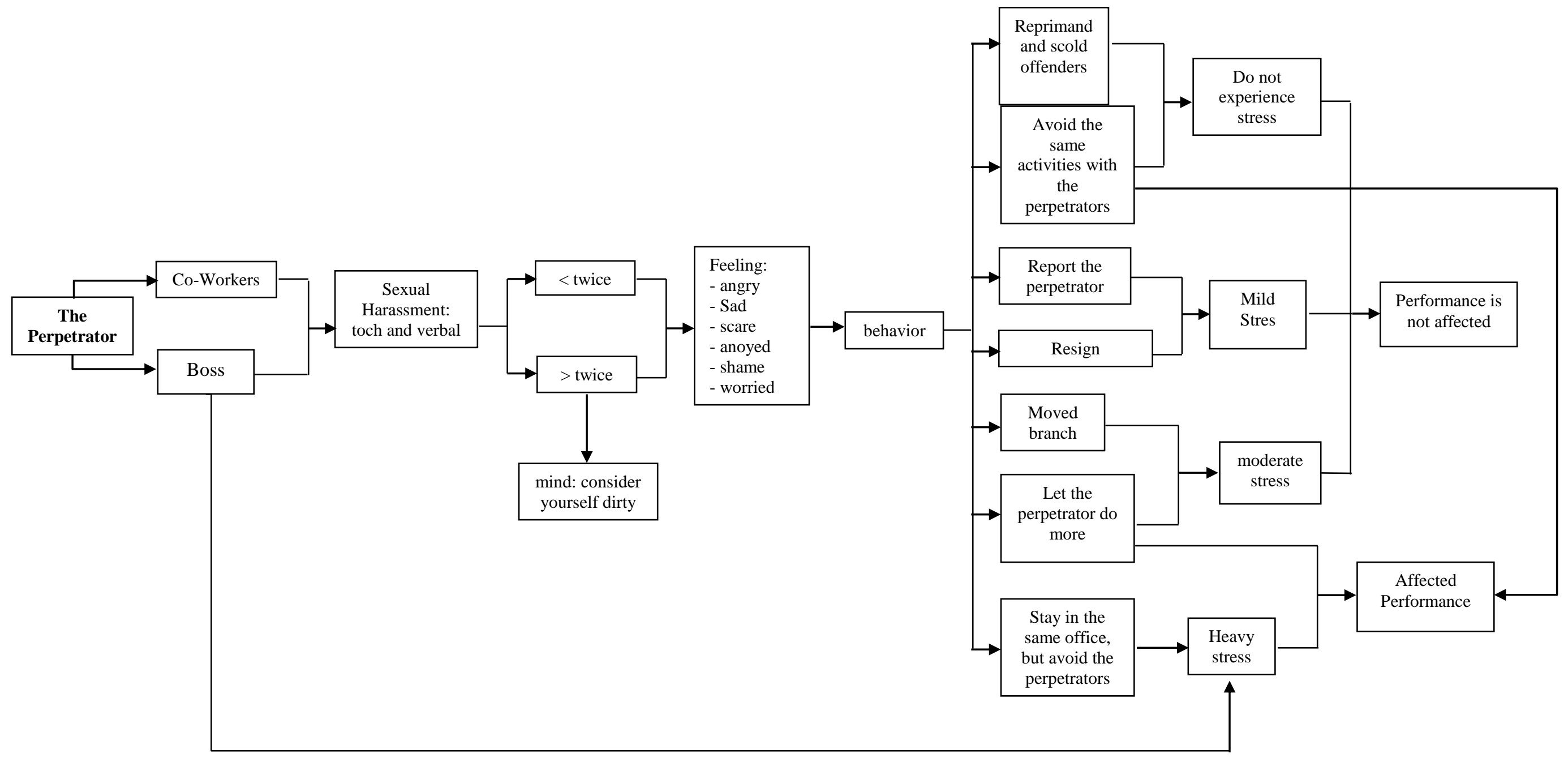

Fig.2. The Phenomenon of Sexual Harassment In Working Women 
Perpetrators of sexual harassment are people who work in the same office with the subject, namely superiors and coworkers. These result are explained by Boland that coworkers or superiors can be sexual harassers. Bosses have a greater possibility of sexual harassment because of authority and power. Boland argued that sexual harassment occurs in verbal and physical forms. Based on the results obtained, the victim experienced sexual harassment in physical form, in the form of touching the buttocks, breasts, and genitals and verbal, in the form of comments about the body shape of the subject.

In some cases, women who are victims of harassment risk losing their jobs or opportunities for career advancement if the request of the offender has a rejection. In other situations, coworkers' unwanted sexual behavior makes working conditions unfriendly and puts indirect pressure on them to leave work. Sometimes, emotional and physical consequences are reactions that arise as a result of the abuse received leaving the trauma for the victim so that they are unable to carry out their duties and responsibilities optimally [17].

The incidence of sexual harassment led to negative feelings, such as anger, sadness, fear, resentment, worry, and shame. These negative feelings explained by Boland as a result of sexual harassment also make the victim experience emotional problems. The results of The Workplace Stress Scale show that only one subject did not experience stress, while nine subjects experienced stress. One cause of stress at work is sexual harassment [18]. Victims will experience stress levels that tend to be high, even traumatized if the offender is the boss. This happens to subjects who experience severe stress due to the position of the offender who is superior and still works in the same office as the offender. Further explanation about stress explained by Lazarus \& Folkman that stress is a relationship between individuals and the environment where individuals get behavior that is not in accordance with expectations and also behavior that makes psychological conditions become negative [19].

One factor that can affect the level of stress is the source of stress, in the form of the frequency and intensity of someone dealing with sources of stress [20]. This explanation occurs in subjects experiencing moderate stress and severe stress-Source of stress, in the form of perpetrators and sexual harassment behavior. The intensity of the subject which is still in the same work environment as the perpetrators and also the frequency of sexual harassment that occurs repeatedly makes the subject experience moderate and severe stress.

Lenhart argued that some sexual harassment victims experienced a fear of punishment in the form of salary deductions or no additional salary [20]. Fear can make the victim finally let sexual harassment still happen to him. Subjects who decide to resign from work, move to another branch, and avoid the offender, are forms of behavior that result from sexual harassment

When sexual harassment occurs in the work environment, the victim will show decreased work performance because of his inability to concentrate his concentration at work [2]. One factor that influences employee performance is security [14]. It is not obtained by some subjects who remain in the same work environment as the perpetrators where the subject experiences fear and worry when called by superiors into the room and meet the perpetrators in the work environment, thus affecting the subject's performance, which then makes the subject unable to focus on work and decreased performance.

\section{Conclusion and Suggestion}

\subsection{Conclusion}

Sexual Harassment experienced by victims is done by superiors and coworkers in the form of touch and verbal. The type of sexual harassment experienced by the subject also varies. Nine subjects experienced sexual harassment, in the form of touch in the buttocks, breasts, and genitals. One subject experienced sexual harassment in verbal form, such as comments about the body shape of the subject and sexual harassment by almost all colleagues. The frequency of sexual harassment experienced by the subjects was six people experienced once, one person experienced it twice, and three people experienced it more than twice.

Based on the results of The Workplace Stress Scale, it was found that subjects who experienced sexual harassment experienced various levels of stress. The causes of stress experienced by the subject after the sexual harassment event vary, such as the position of the perpetrator in the workplace, the frequency of sexual harassment, the intensity of the subject meeting with the perpetrator, the number of perpetrators, the behavior that appears after the incident, and the negative feelings that arise due to sexual harassment.

Other data found is the influence of sexual harassment events on the subject's performance at work. However, this only happened in eight subjects in the form of frequent subjects making mistakes while working, absenteeism 
decreased, and less able to concentrate on completing work while the other two subjects did not experience changes in performance because of the intensity of the meeting non-routine actors.

\subsection{Suggestion}

Supervision of the implementation of regulations from the government as an effort to protect working women. In addition, different locations and research subjects may have different results.

\section{References}

[1] Perempuan, K.: "Tergerusnya Ruang Aman Perempuan dalam Pusaran Politik Populisme," Catatan Kekerasan terhadap Peremp. Tahun (2017)

[2] Boland, M. L.: Sexual harassment in the workplace. SphinxLegal (2005)

[3] Pranantya, R. A.: "Iklim Organisasi Dan Sifat Pekerjaan Sebagai Penyebab Terjadinya Pelecehan Seksual Dan Pengaruhnya Terhadap Motivasi, Stres Kerja, Kepuasan Kerja, Serta Kinerja Karyawan,” J. Manaj., vol. 6, no. 1 (2016)

[4] Nasional, B. K. K. B.: "Buku Suplemen Bimbingan Teknis Kesehatan Reproduksi Pelecehan Seksual." UNESCO: Jakarta, (2012)

[5] Howard, L. G.: The Sexual Harassment Handbook: Protect Yourself and Coworkers from the Realities of Sexual Harassment, Take Action, Investigate, and Remedy Accusations of Harassment, Create Corporate Policies that Educate and Empower Employees. Career Press (2007)

[6] Sugerman, L., "MeToo in Traditionally Male-Dominated Occupations: Preventing and Addresing Sexual Harassment. Chicago: Chicago Women In The Trades," 2018. [Online]. Available: http://womensequitycenter.org/wpcontent/uploads/2017/10/CWIT-MeToo-in-Male-Dominated-Jobs-003.pdf.

[7] Teguh, W.: "Menghadapi stres dan Depresi: Seni Menikmati Hidup Agar Selalu Bahagia." Yogyakarta: Tugu Publisher, (2009)

[8] Robin, S. P., and Judge, T. A.: "Perilaku Organisasi Edisi 12.” Jakarta: Penerbit Salemba Empat (2008)

[9] Luthans, F.: "Organizational Behavior Twelfth Edi-tion.” New York: The Mc Graw Hill Companies Inc (2011)

[10] Ivancevich, M. Konopaske.: Organizational behavior and management _ John M. New York: Mc Graw-Hill Companies Inc (2008)

[11] Hasibuan, M.: "Manajemen Sumber Daya Manusia, edisi revisi Jakarta: Bumi Aksara," Jakarta Bumi Aksara (2009)

[12] Sutrisno, E.: "Manajemen Sumber Daya Manusia Edisi pertama," Jakarta Kencana Prenada Media Gr (2009)

[13] Fauzi, F.: "Pengaruh stres kerja terhadap kinerja karyawan: Studi pada CV. Gunung Jati Probolinggo Jawa Timur." Universitas Islam Negeri Maulana Malik Ibrahim (2013)

[14] Pasolong, H.: "Teori Administrasi Publik, cetakan kedua," Bandung Alf. CV (2010)

[15] Creswell, J. W.: "Research Design Pendekatan Penelitian Kualitatif, Kuantitatif, dan Mixed," Yogyakarta: Pustaka Pelajar (2009)

[16] Creswell, J. W.: "Penelitian kualitatif \& desain riset: memilih diantara lima pendekatan," Yogyakarta: Pustaka Pelajar (2015)

[17] "Sexual Harassment - Effects of Sexual Harassment." [Online]. Available: http://hrlibrary.umn.edu/svaw/harassment/explore/4effects.htm.

[18] Fitzgerald, L. F., Swan, S., and Fischer, K.: "Why didn't she just report him? The psychological and legal implications of women's responses to sexual harassment," J. Soc. Issues, vol. 51, no. 1, pp. 117-138 (1995)

[19] Folkman, S., and Lazarus, R. S.: "If it changes it must be a process: study of emotion and coping during three stages of a college examination.," J. Pers. Soc. Psychol., vol. 48, no. 1, p. 150 (1985)

[20] Lenhart, S. A.: Clinical aspects of sexual harassment and gender discrimination: Psychological consequences and treatment interventions. Routledge (2004) 